\title{
Coastal Yorubaland: Habitability, Inhabitance, and Inheritances
}

\author{
Toyin Falola \\ University of Texas, USA \\ toyinfalola@austin.utexas.edu
}

\begin{abstract}
Although the conference from which this Special Issue derives was convened by two prominent historians, this article is multi-disciplinary; both within and outside the boundaries of history. The purpose is to merge various ideas in different disciplines to argue that the study of Coastal Yorubaland as an important unit of analysis should, on the one hand, stand alone, and, on the other, be integrated into larger studies in all fields from Art to Zoology. For thousands of years, people have been living along the coast, experiencing interactions with the sea: they were shaped by the lagoon and sea, and they in turn shaped the coastline and waterways. The past of the coastal Yoruba people shapes their present, and this present will shape their future. In this article, I speak to the impact of the consciousness of history, the consciousness of the past, and the consciousness of self and identity on coastal Yorubaland.
\end{abstract}

\section{Introduction}

The geographical area that shaped the conference and this article is located along the sea and the Lagos lagoon, particularly the clusters of communities along the lagoon itself, as well as the long and beautiful stretch between Warri to the east and Lagos to the west. Communities live on land, on the sea, and along the waterways that connect sea to land and one community to another. Among the major groups that occupy the coastal parts are the Ilaje, the Ikale, several subgroups of the Ijebu, the Awori, and such related identity groups as the Ijo [Ijaw], Itsekiri, Apoi, and Urhobo, to mention but a few. Here is how Daryll Forde described a part of the region in 1951: 
The coastal zone, about 12 miles wide, raised only slightly above sea level, consists of peninsulas, islands, sandbanks, lagoons and swamps. The surface is composed of marine and river sand with alluvium and decaying vegetable matter and the whole area is more or less covered with aquatic plants, mangrove and forest vegetation. A lagoon system, running the full length of the Yoruba coastline and providing an inland waterway from Cotonou in Dahomey to Benin in the east, is a striking feature of the coastal zone. ${ }^{1}$

Coastal Yorubaland is part of the long ancient history of Nigeria. But the region has mostly been ignored by archaeologists, perhaps due to limited research funding and shortage of professionals to carry out the much-needed fieldwork. Indeed, I have had an occasion, in the company of Dr. Adisa Ogunfolakan, the archaeologist at Ife, to plead for excavation at Ugbo, to determine the antiquity of the place and to set out comparative work with archaeological findings at Ile-Ife.

Part of the coastal region entered the written historical records as far back as the sixteenth century. The coastal states of Ijebu feature in an account written by the Portuguese writer Duarte Pacheco Pereira, ${ }^{2}$ while J. Adams surveyed Lagos in the eighteenth century. ${ }^{3}$ Sources on the Yoruba hinterlands came later, although they have now established dominance in the literature. By 1852, when the British installed a consul in Lagos, the sources on some parts of the coastal Yoruba began to expand exponentially, with Lagos becoming the most written about. ${ }^{4}$ For a long time most other parts of coastal Yorubaland did not benefit from being included in historical sources or from the interest of local historians. Even during the colonial era, works were few and far between. ${ }^{5}$

1. Daryll Forde, Ethnographic Survey of Africa: Western Africa, Part IV: The Yoruba-Speaking Peoples of South-Western Nigeria (London: International African Institute, 1951), 5 .

2. Duarte Pacheco Pereira, Esmeraldo de Situ Orbis, trans. and ed. G. H T. Kimble (London: Hakluyt Society, 1937).

3. J. Adams, Remarks on the Country Extending from Cape Palmas to the River Congo (London, 1823), 93.

4. Books on Lagos are many. Among others, see A. Onikoyi, The History of Lagos (Lagos: Self Published, 1975); A. B. Aderibigbe, ed., Lagos: The Development of an African City (Lagos: Longman, 1975); T. A. Folami, A History of Lagos, Nigeria (New York: Exposition, 1982); P. Cole, Modern and Traditional Elites in the Politics of Lagos (Cambridge: Cambridge University Press, 1975).

5. See, for instance, National Archives, Ibadan, CSO 2629979, 29664, Intelligence Report on the Central Awori Group in Ikeja and Badagry District of the Colony by R. J. M. Curwen, District Officer. 
Without lending support to the theory of geographical determinism, it can be said that location plays a significant role in the formation of the coastal communities as they interact with the lagoon, sea, and waterways in shaping economic and spiritual activities. If fishing is central to the people's occupations, this is itself connected with a spiritual complex that privileges gods and goddesses associated with water. In spite of the significance of this area, it has thus far been marginalized in both academic and practical manners. Why the marginalization? This should be the starting point in any discussion on coastal Yorubaland.

\section{Marginalization}

Lagos and Badagry are well represented in the literature, but not the rest of the coastal subregion. The Lagos-centric approach, which is dominant, is severely limited because Lagos does not fully represent the subregion; the people of Lagos cannot speak for the rest of coastal peoples. The brief mention of the Awori and Ikale can be noted in Samuel Johnson's History of the Yorubas, a practice that is found in most of the local histories that were to follow, although most authors focused on the specific cities where they were born.

The marginalization is rooted even in the mythology that speaks to the centrality of Ile-Ife as the origin of the Yoruba (and sometimes of the entire world and all races). In that mythology, the supreme God sent human beings to create land, plants, animals, and other objects. All the rivers, sea, islands began as an act of that creation. It is essentially a mythology located in the hinterland, in which people moved from this hinterland to populate the coast. So also, are the variants of the legends constructed around Oduduwa locked in a hinterland metanarrative. ${ }^{6}$ Could the settlement of some parts of the hinterland not also have been from the coastal areas, as one variant of Ugbo mythology, described below, advances?

As scholars began to write about the Yoruba from the 1950s onward, the coastal Yoruba were further ignored, except again Lagos and Badagry. In Sources of Yoruba History, edited by Professor S. O. Biobaku, which heralded the success of Yoruba studies, there was not a mention of the Awori and Ilaje, and only Ikale dialect receives two brief passing mentions. References to written sources, oral sources, literature, ceremonies, archaeology, art in metal and

6. Various mythologies have been reported in different books. See, for instance, Samuel Johnson, The History of the Yorubas, 3; M. A. Fabunmi, Ife: The Genesis of Yoruba Race (Lagos: West, 1985); Folorunsho Afodunrinbi, Topics on Yoruba History (Lagos: New Millennium Communications, 2000), 3-10; J. A. Atanda, An Introduction to Yoruba History (Ibadan: Ibadan University Press, 1980). 
wood, and social and political structure do not allude to the coastal Yoruba people, and the examples and thematic homogenization of the Yoruba were drawn from non-coastal polities. ${ }^{7}$

Pay attention also to the definition of kingship, and you will see notable omissions. Stories are woven around kingship, and early mythologies connect kingship with nations. Oduduwa is treated in such stories as a king, who in turn produced children whose number ranged from seven to 50, as accounts differ. The children are then presented as princes who settled elsewhere to become the first kings. In one of the earliest lists by Samuel Johnson, seven names were listed: the Ila, the Owu (Owu-Ipole), the Benin, the Sabe, the Ketu, the Popo, and Oyo. In recent, expanded lists produced by a variety of authors, the "tribes" of Oduduwa often break down into 21 kingdoms including coastal ones. These include Afemai, Akoko, Apoi, Awori, Ekiti, Edo, Egba, Egbado, Eko, Ifonyin, Ife, Igbomina, Ijebu, Ikale, Ilaje, Ilorin, Ipokira, Itsekiri, Iyagba, Kabba, Ketu, Ondo, Owo, Oyo, and Remo. ${ }^{8}$ In this list by L. A. Adetunji, coastal Yoruba is fully inserted as having a history that dates back to the very beginning, that is, a direct link to Ile-Ife and to Oduduwa.

Yet in another list of kings with titles by the same L.A. Adetunji, many coastal kingdoms are missing. He lists Onibini of Benin; Ajagunla, Orangun of Ila (Igbomina); Soropasa, Alaketu of Ketu; Ajalake, Alake of Egbaland; Oloyo (Alaafin) of Oyo; Ajibogun, Owa of Obokun of Ijesa; Olugborogan, Awujale of Ijebu; Obarada of Dahomey; Oninana (in Ghana); Onipopo of Popo; Onisabe of Sabe; Osemawe (Pupupu) of Ondo; Akarigbo of Ijebu Remo; Deji Ajaponda of Akure; Ajibosin, Olowu of Owu; Elewi of Ado-Ekiti; Olowo Arere of Owo; Akarawale, Alara of Ara; Ajero of Ijero; Owafanran, Owore of Otun; Akinsale, Elekole of Ikole; Akinsale, Elekole of Ikole; Oloshi of Oshi; Alaaye, Ipole of Aaye; Olojudo of Ido; Owa Aringbajo of Igbajo; and Owa Otan of Otan Aiyegbaju. ${ }^{9}$ In this list is an omission by definition, that is, it includes only those defined as the original princes with direct connections to Ile-Ife, although it must be added that there are secondary list of migrants with princes leading people to various places to create kingdoms.

The mythologies and other interactions lead us to use the generic name "Yoruba," and the specific names of the subgroups, as in Ilaje and Ikale. In the generic are also delineated common characteristics as the use of Yoruba as a language (with multiple dialects) and as a linguistic group, traditions of an

7. S. O. Biobaku, Sources of Yoruba History (Oxford: Oxford University Press, 1973).

8. Prince L. A. Adetunji, The Glory of Yoruba Nation (Lagos: Lichfield, 1999), 30.

9. Ibid., 31. 
origin linked to Ile-Ife, and cultural similarities. ${ }^{10}$ But we also study the Yoruba in their specific subgroups, as in works on Ikale. Studies on the specific Yoruba subgroups reveal many variants of mythologies that do reinforce the Ile-Ife hegemonic ones, and some that depart substantially, as in the case of the Ijebu claiming their origin in the Sudan.

Yet, the key issue in linking the people of coastal Yoruba to either the rest of the Yoruba or to Benin is very much tied to stories of origin. Thus, there are those, as mentioned below, that establish ties to Ile-Ife to claim significance within the concept of pan-Yorubana. However, departures from the common Yoruba mythologies do exist among the coastal Yoruba, and three can quickly be mentioned. First are some versions tracing origins and migrations from Benin, instead of from Ile-Ife. Sure, elements of Benin's impact on these societies are very clear. Second, there is the Ugbo version saying it is older than Ile-Ife. Third, there are narratives on non-dynastic lineages that are not tracing their early history to a prince from Ile-Ife.

For instance, in Losi's account of Lagos, he provides a mythology that Lagos started from Iseri, on the River Ogun, about twenty miles away from Lagos. According to Losi, the founder was a hunter, Ogunfunminire, who attracted others to the settlement. As a reward, Ogunfunminire was given an Ife title, Olofin Awogun-Joye, cleverly connecting the foundation story back to Ile-Ife, but not to the well-known one of the migrating princes. From Iseri, people moved towards Lagos, described by Losi as a "bush full of swamps and lakes." ${ }^{11}$ A king eventually emerged, with a palace that derived its name from the pepper tree of Iganran, and Iga, a name for a palace. In Losi's story, Lagos became a mix of people from among the Awori, Egba, and Ijebu. And very early in his narrative, Losi brought in Benin in the context of ongoing warfare and domination. Benin was able to establish both cultural and political influence, at some point one of its men becoming the most powerful warrior.

If some mythologies are silent on the coastal Yoruba, so too are the many projects of collecting oral traditions since the 1950s, which have often excluded them. Preference for research projects has been focused on the big king-

10. See, for instance, S. Labanji Bolaji, Yoruba Living Heritage (Ibadan: Omoleye Publishing Company, 1984); Hali Sadia Issah, Yoruba Customs and Institutions: An Annotated Bibliography (Lagos: Concept Publications, 1988); S. O. Biobaku, Egba and their Neighbors (Ibadan: Ibadan University Press, 1991); Adetunji, The Glory of Yoruba Nation; N. A. Fadipe, The Sociology of the Yoruba (Ibadan: Ibadan University Press, 1970); Folorunsho Afodunrinbi, Topics on Yoruba History (Lagos: New Millennium Communications, 2000).

11. John B. Losi, History of Lagos (Lagos: Tika-Tore Press, 1914; reprinted 1967 by African Education Press, 1967), 3. 
Toyin Falola

doms. Not a few have made the point that coastal topography is a hindrance, as the waterways, lagoons, swamps, and sea make research difficult.

Another note on marginalization: with the exception of Badagry and Lagos, Yoruba coastal areas did not make it to many textbooks on Nigerian history. Even then, both Badagry and Lagos are represented in part because both were connected with the trans-Atlantic slave trade; and in the case of Lagos, because it was the country's capital for most of the twentieth century.

The origins of Nigerian history as an academic endeavor were deeply connected with nationalist historiography, which called for the advancement of the project of past glories and connections between indigenous institutions and modern ones. In the nationalist tradition, African institutions and leadership must acquire positive images. In this thinking, emphasis was placed on empires, leadership, state formation, kings, and wars. Societies perceived as small-scale were less regarded. History and ideologies of power are always very much connected. Narratives on empire are also about domination, and in the case of Yoruba history, the Oyo-centric narrative of the empire, as in the one told by Samuel Johnson, marginalized the histories of other subgroups.

The omission of these areas in the literature needs to be corrected. Efforts have started, and a few scholars have broken the silence and are changing the historiography by studying the coastal areas, building on the works of previous local historians, like the well-cited work of John B. Losi, a schoolteacher and prince of Abeokuta who wrote on the Awori, ${ }^{12}$ and T. Ola Avoseh on Epe and Badagry. The notable scholars who have continued to expand our knowledge of the coastal Yoruba include Professor Ogen, Dr. O. Ajetunmobi (who examines the migrations and settlement patterns from the fifteenth to the nineteenth century); and Professors G. O. Ogunremi, M. O. Opeloye, and Siyan Oyeweso who co-edited a book on Badagry. ${ }^{13} \mathrm{New}$ frontiers of knowledge have extended to the Awori. A series of papers organized as a seminar series between 1994 and 1997 by the Adeniran Ogunsanya College of Education, located at Oto-Ijanikin in Aworiland, eventually led to the publication of a co-edited book by E. A. Ajayi, R. O. Ajetunmobi, and S. A. Akindele. ${ }^{14}$ The book attests to the slow pace of research on the Awori, efforts to collect new data, and the support of several obas to encourage the expansion of knowledge about their people.

12. Losi, History of Lagos. He supplies two strands of history-the early history of the Awori and the beginning of the Benin encroachment (probably after the sixteenth century).

13. G. O. Ogunremi, M. O. Opeloye and Siyan Oyeweso, eds., Badagry: A Study in History, Culture and Traditions of an Ancient City (Ibadan: Rex Charles Publications, 1994).

14. E. A. Ajayi, R. O. Ajetunmobi and S. A. Akindele, A History of the Awori of Lagos State (Lagos: Literamed Publications, 1998). 


\section{Significance}

Let me now turn to some of the issues regarding the relevance of the need for the insertion of Yoruba coastal areas into a larger historiography. The relevance cannot be overstated; and, indeed, it shapes the title of this article. In geographic space, we are dealing with a large area that could constitute an autonomous state or country, depending on how it is measured, and the artificiality of the partition. Coastal Yorubaland, if taken either in terms of population (and in some cases by land area), is bigger than such countries as Israel, Sweden, Norway, Finland, Belgium, Greece, and a number of other Western European nations, and is possibly closer in population to Senegal, Cambodia, Malawi, Chad, Zimbabwe, Cuba, and Somalia, to mention a few countries with a population of around 12 million.

The region is also integral to the overall development of Nigeria as a nation, and an outstanding but ignored facilitator of the much larger project of the Economic Community of West African States (ECOWAS). Its abundant resources generate revenues for the development of the nation, and regarding ECOWAS, its location makes it a hub for the massive movement of goods through the sea and harbors. And of course, the region is a great source for protein in fish, and the production of salt, to mention but two key products.

Take the example of densely populated Lagos with its harbor, an entry point to Nigeria and the Republic of Benin. Consider the Awori contribution to Lagos, the commercial center of the entire country, a former capital of Nigeria and seat of federal power. If we add up all the achievements of Lagos and the place of the Awori in it, ${ }^{15}$ the relevance of the coastal people becomes far larger than we often present it: they have served as the springboard to initiate and implement modern ideas since the nineteenth century, to organize the colonial administration, and to lead anti-colonial resistance and much more.

Coastal Yorubaland is a connecting bridge to multiple peoples and histories: to the Yoruba hinterland where it merges narratives with states and empires; to interactions and migrations westward, from the Republic of Benin to the Gambia; to migrations eastward, from areas incorporated to the mighty Benin Empire; and to interactions across the Atlantic, in a long history shaped by the devastating and brutal Atlantic slave trade.

Coastal Yorubaland supplies the bridge that links places to environmental history. Indeed, it is awaiting the first narrator of its environmental history. Potential topics abound: histories of plants and land; nature and nurture; environment and culture. The region is livable-in, which is why I am using the

15. K. Faluyi, "The Awori Factor in the History of Lagos," in History of the Peoples of Lagos State, ed. by A. Adefuye et al. (Lagos: Lantern Books, 1987). 
term inhabitance. It is rich in resources, a valuable habitat. And through the intelligent combination of people and resources, it has given us a key heritage in rich ocean resources. As people interact with this unique environment, they in turn create cognitive practices that have changed themselves and changed the region.

There are issues around the frontiers, at the edges of interactions, the boundaries with the hinterland. The frontiers are spaces for interactions that produce their own subcultures and alternative ideas. Indeed, micro-histories of the three coastal groups suggest how ancient they are, as in the Ugbos' connections with Ile-Ife dating back to antiquity. But more important are stories of movements from the coastal Yoruba to other places, and from other places to the coast. There are even references in mythologies to a group whose identity is unknown who once lived there before the Yoruba. Similar mythologies abound elsewhere, as in those relating to the pre-Oduduwa era at Ile-Ife.

Frontiers also illustrate how humans and groups expand into spaces they think are new or they could dominate and influence. Mythologies and stories in all the coastal areas are full of fluidity in migrations. Some mythologies claim that hinterlanders moved there, as those of the creation of the Ijebu coastal groups. The frontiers merged into zones of imperial domination, not unusual in history, as weaker groups could become dominated by stronger states. In this case, the mighty Empire of Benin saw a good opening to its west, and it made a good use of it through conquest and domination.

Interfertilization must be seen as a common occurrence in the history and experiences of the coastal Yoruba. Here the dimensions are many. One is that of imperialism with Benin's influence. Another is that of the Atlantic world with ideas and commodities (like cassava) coming from the Americas. A third is the overall composition and character of Yoruba culture with elements from all its neighbors-the Edo, Nupe, Bariba, Aja, and also elements of Yoruba culture in those groups as well. The absorption of those other elements was similarly shared by those in the coastal land. Examples include institutions of the family, religion, and politics, as well as economic and political practices.

Mythologies are deeply encoded in interfertilization. Indeed, stories of migrations reveal the spread of ideas, telling us who borrowed from whom. In the process, centers of civilization are invented, with a location claiming credit as the primary source of ideas. For instance, the hinterland story of Ife as the center of creation is also about a claim to civilization. Scholars recognize in the Ife story not just its discursive claim to being the center of creation, but also the subtextual claim to civilization, just as they recognize these elements in variants of the story from other locations. The Benin mythologies, many of 
which have been popularized by Jacob Egharevba, ${ }^{16}$ are replete with ideas on interfertilization, suggesting that Benin and Ife were linked by kingship and dynasties.

Some aspects of the coastal histories may not be easily connected with the general outline of Yoruba history as laid out by N. A. Fadipe, G. J. A. Ojo, and S. A. Akintoye. The homogenized account of the Yoruba is that they lived in walled cities (settlements along the coast were not walled in that conventional sense), were highly urbanized (not all coastal areas were big in size), and that they evolved a strong monarchical system (some coastal cities did and some lived in small chiefdoms).

Some developments found in the history of coastal cities are truly innovative. When one reviews the history of Lagos and Badagry, one sees their pioneer status in education, spread of Christianity, and innovative aspects of what is generally called "European civilization." The initial number of literate Yoruba was concentrated in Lagos, with a major impact on the rest of the country.

\section{Emerging Themes}

The organizers of this conference were extremely generous in laying out the themes and topics that should dominate our attention, focusing on three broad ideas of community, trade, and religion. ${ }^{17}$ Community deals with people, villages, towns, institutions, and politics, as they are organized into constituencies and identities, and as they occupy places and spaces. A community is not an island unto itself, but connected with other communities near and far. In the composition of communities and inter-group relations, the organizers wisely isolated the elements of religion, trade, and politics.

All three-religion, trade, and politics—can be studied independently, but also as a web of inter connections. As a web, religion, intellectual history, and economics are suffused with politics. Religion cannot be studied or understood without the knowledge of political history. Daily religious practices, as part of social structures, are also a significant part of a society's political interactions. Political leadership, political discussions, and power politics ultimately constitute all aspects of culture. All ideas engage the discourses of power. Societies comprise communities constituted into identities-as Muslims, Christians, traders, and others. Their activities and the histories they generate,

16. Jacob U. Egharevba, A Short History of Benin (Ibadan: Ibadan University Press, 1968).

17. "Community, Trade, and Religion in Coastal Yorubaland," last modified February 18 2016, http://www.knowingeachother.com/2016/02/18/community-trade-and-religionin-coastal-yorubaland/. 
however, are projects of power and politics. The introduction of Islam and Christianity to the coastal parts is about politics-the politics of evangelization, the politics of imperialism, and the politics of the imposition of so-called universal ideas.

As some of the contributors are most likely to address, all regions of the world deal with three essential elements in their history: the key turning points, the trends, and political activism that generates changes. The three forces of religion, trade, and politics will have their impact at one time or other. The introductions of Islam and Christianity have been great turning points to those communities in the nineteenth century and after. Religious societies emerged in organized forms as movements to insert themselves into power. As the societies became more complex, created political institutions to manage themselves. By the time we encounter complex cults and religious practices, we are also dealing with institutions of complex societies. These institutions, including those of religion, actually became part of the formation and character of politics. As communities try to assert themselves or create processes to become semi-autonomous kingdoms, they ultimately evolve ideas of power and independence.

The historical narratives of coastal Yorubaland are strong on the outcome: distinct precolonial societies emerged, each with a name, organized around a set of elites whose dominance was underwritten and justified by religious practices and the exercise of power. Studied independently, a pattern emerges of distinctive local religions, and the later spread of Islam and Christianity.

When the extant literature on coastal Yorubaland is itemized, three major clusters emerge: the first on Lagos and its neighbors, the second on Badagry, and the third on the Yoruba and related groups west of the Niger Delta, notably the Mahin, Ikale, Ilaje and their several peninsula neighbors. Coastal Lagos and its people are one of the earliest to enter the historical records, with an impressive output in the nineteenth century from a combination of sources-missionaries, European visitors, officials associated with the consulate, traders looking for profit and business expansion, and an emerging Yoruba Western-educated elite. Local voices can be found in the newspapers of the period. Much of this information has been put to good use in an impressive body of scholarship on both Lagos and Badagry. Some publications really stand out, as in the Honorable J. A. Payne's Almanac as well the newspaper, Iwe Irohin Eko. Local chroniclers also made their own contributions. By 1914, John B. Losi published his widely consulted book, History of Lagos. It was originally written in Yoruba, a project he started in 1910, instigated by the manager of the Roman Catholic Church. A very modest man, Losi confessed that his was a daunting task. Badagry is covered in such works as by 
Avoseh ${ }^{18}$ and much later on by a number of citizens interested in the history of their famous town. ${ }^{19}$ Lagos continues to receive scholarly coverage and recognition. ${ }^{20}$

Historiographically speaking, the literature surrounding the Ikale and Ilaje is arguably the least-developed. More work has to be done, indeed with high degree of urgency. To be sure, many of the prominent citizens from this part of coastal Yorubaland have long been conscious of the need to preserve their history. For instance, High Chief Fadesola Akinola Iyaomolere (1911-1996), with the adopted titles of "the Dosu Onekomabaseyi of Mahinland" and the First Secretary General of the Mahin Council of Obas and Chiefs, was fond of telling myths and stories of the Mahin people to his children and researchers. One of his children, 'Tade Iyaomolere, a school teacher, later took up the challenge to write an account derived from traditional narratives, The Ilaje Country of Mahin, published in 2011. ${ }^{21}$ On the dedication page, he describes his father as "a wonderful historian and teacher of teachers."

As scholarly works focus on different cities and places, let me sum up all the themes that have attracted publication to date. When all the scholarship clusters are combined, they do reveal a consistency in motives and themes. The themes consolidate our knowledge of coastal Yorubaland, while enabling us to identify the gaps and to extend our frontiers to newer fields. It is extraordinary to note that the motive that drives the local historians in the coastal parts is the same that drove the earlier narrators dating back to Samuel Johnson in the nineteenth century. To cite the example of Iyaomolere:

'Don't we have a history?' [was a question] posed to me by one of my students at Gbabijo High School, Gbabijo. On reflection, I resolved to prove that we have a history. As I mulled over how to go about writing this book, it struck my mind that I should ransack Amapetu's documents that I was saddled with the task to look after, upon the death of my father, High Chief Fadesola Akinola Iyaomolere.... These docu-

18. T. Ola Avoseh wrote a number of small pamphlets on Badagry and Epe. Among his works are A Short History of Badagry (Lagos: Ifeolu Press, 1938); A Short History of Epe (Apapa: Adeolu Press, 1960); Iwe Itan Isin Imale Ni Ilu Agbadarigi (Apapa: Adeolu Press, 1960); The History of St. Thomas's Church Badagry 1842-1970 (Apapa: Adeolu Press, 1970); The Historical Tree of Badagry (Apapa: Adeolu Press, 1984); Iwe Itan Kukuru Egbe Ajumogbadura (Apapa: Adeolu Press, 1973).

19. See, among others, African Renaissance Foundation, Badagry: The Cultural Heritage (Lagos: AREFO, 2000).

20. See, for instance, Takiu Folami, A History of Lagos, Nigeria (New York: Exposition Press, 1982).

21. 'Tade Iyaomolere, The Ilaje Country of Mahin (Akure: Self Published by Alabi-Eyo and Co. Ltd, 2011). 
ments enabled me to gain real insight into Mahin History. The exposure strengthened my resolve and restored my confidence as well as made me feel competent to put this piece together. Therefore, this book is specifically written in the interest of posterity, because of the speed at which aged persons that are repositories of our culture and ancient history are sleeping with their progenitors. There is also the issue of youths' lukewarm attitude towards history. If steps are not taken to arrest this dangerous trend, with passage of time, generations which will follow, will find it extremely difficult to know where they came from and, by implication, where they are going. If the past sinks into oblivion, the present will not only be impossible to fathom but also be difficult to predict the future. ${ }^{22}$

I have quoted this remark at length, with its language errors, as it shows a number of characteristics. Iyaomolere was interested in writing, but he needed to establish the authority to write, to lay claim to the authenticity of voices, and to position himself as a credible citizen. To establish a claim to authority is to reference the sources and their credibility. The paucity of written information is a problem, indeed with a wide gap between 1937 when R. J. M. Curwen compiled the Ilaje Intelligence Report ${ }^{23}$ and when Iyaomolere's book appeared. Without printed books, the author had to validate the use of traditional history and establish a firm connection between it and kingship. In this instance, the king is the repository of knowledge. He added other pieces of information, some of which he claimed to remember from speaking with many Mahin elders. Then he added proverbs, ceremonies, and festivals that he observed. He is clear as to the reasons why he writes, and the purpose the narrative is to serve.

Many of the works locate their towns and people under study into the larger regional framework of Yorubaland. In trying to reconstruct specific histories, they locate early beginnings in the conception of dispersals and migrations, thereby accepting the supremacy of the Oduduwa story and that of Ile-Ife. 'Tade Iyaomolere sees the origins of the Mahin in the migration of the sons of Ora or Oduduwa. The migration stories are always complicated, as they trace not just the beginning of a history, but relationships with other places and ethnicities.

For example, the book tells how the Mahin people left Iddo, Ile-Ife, for Ilaje in Ipetumodu, shortly for Igo, in the present day Edo State, later Igoro in Delta

22. Iyaomolere, The Ilaje Country, iv.

23. National Archives Ibadan, Ilaje Intelligence Report, Ondo Prof. 1/1, File No.119, RJM Curwen, 1937. 
State, before they eventually settled at Ode Mahin and its environs under the leadership of Oba Agoro. The people of Mahin also founded places such as Omi, Iladu, Ogbelaka, Akara, Egudu, Aba Alagwe and Iparamo in the present day Edo and Delta States. It also covers exploits of past Amapetus, Mahin in the melting point, return of peace, installation of titles, how Mahin Kingdom is governed, satellites of Mahin, their economic activities, socio-cultural institutions, passage, burial and life after life, their religious beliefs, Christianity in Mahin, outstanding sons and daughters of Mahin Kingdom as well as Mahin in the March to Democracy in 21 st century Nigeria. ${ }^{24}$

Several books examine the history after the initial founding, tracing specific events and achievements to specific kings and rulers. Conflicts and wars are reported as part of this narrative, with praise of successful warriors, condemnation of traitors, devastating words for enemies. Some authors weave their narratives around their successful sons and daughters, as in Ajibola Salako's book on Ota. ${ }^{25}$

The history of the entire region is replete with stories of human migrations and political trends. It remains unclear whether the coastal topography hindered the penetration of the terrain by hinterland states whose militaries were more attuned to fighting on land. Other than in mythologies around non-humans, people did not come from beyond the sea. What happened to the people before we encounter the stories of human activities? Whether the account be that of Avoseh on Epe or Losi on Lagos, it is full of people moving into the coastal region. They all start with the mythologies of a void, where no one really knew the color and characters of the earliest inhabitants. Some were spirits and non-humans from the sea, strange looking creatures who were fish-like but also looking for fish to eat. All these stories can be regarded as autochthonous, that is, the current people did not fully know those before them and/or in some ways claimed an affinity or relations to those who originally populated the place. Where stories of origins link human ancestors to that very place, it makes a connection to what is organically related to the land, and it is a way of saying that the people own the place, and owe their existence to no one and no other group.

The stories of conquest are then imposed as a fresh layer over the autochthonous ones, and each story usually begins with a kingship or a dynasty. It is in this phase, roughly the second phase, when one mythology is piled on top of another, that they begin to label a place (as in Iseri, Epe), and name rulers (as in Ogunnifunminire of the Awori), or name occupations (as in hunting).

24. Ibid., v.

25. Ruhollah Ajibola Salako, Ota: Biography of the Foremost Awori Town (Ota: Self published by Penink Publicity, nd 1998?), 1. 
As names and labels are descriptive words, this phase may also mark the origins of language, as people use ancient words centuries later and began to associate them with some historical meanings. It is not easy to understand how languages and various dialects emerged, but those who narrate mythologies use both ancient and contemporary words to describe a long lost past.

The mythologies, however, do more than this. They tell of how existing groups were assimilated or eliminated, suggestive of how a new identity, usually with a name, was created, which explains why we have distinctive groups such as the Ikale, Awori, and Ilaje. A new archive is created, comprised of the records of the conquerors, and we only know about the conquered in a limited way since history is written by the conquerors.

Concerning both the first and second phases of these mythologies, only archeologists can fill the gaps and resolve many issues. The dates imposed by scholars, such as when they say that these events occurred before the fifteenth century, have to be taken as basically conjectural. One way to expand the knowledge base may be to track the evolution of words and phrases, and link them to a body of ideas. For instance, if the name of the founder of Iseri is linked with Ogun, the god of iron, knowing more about Ogun will be useful, although this, too, will never be conclusive. The early history of the Awori suggests the use of iron, and the oral accounts of the events and conquests, located at Iseri, may also suggest that the initial stages of settlement took place inland, rather than along the sea, from whence conquerors gradually proceeded to the waterways, lagoons, and the coast. Dr. Ajetunmobi identified some settlements, probably frontiers, such as Iro, Ota, Idoko, Ifore and Igodo, ${ }^{26}$ from whence advances were made to conquer and control the coastal parts. Dr. Ajetunmobi sees two powerful centers which later became the clusters of heavily populated settlements that led to the formation of kingdoms: Iseri in the west and Ugbo in the east. To him, our understanding of the growth of this region must acknowledge the role of the Awori and Ilaje. It is necessary to quote his argument here:

The series of migrations and wars of conquests crystallised into the formation of the Isheri kingdom among the Awori and Ugbo kingdom among the Ilaje. The two kingdoms developed as dispersal centres for adventurous individuals, warriors, as well as those seeking political freedom and social security. This has been confirmed by traditions of many later Awori and Ilaje settlements who trace the origins of their ancestors and settlements to the founding fathers of Ugbo and Isheri. ${ }^{27}$

26. R. O. Ajetunmobi, Coastal Yorubaland of Nigeria, 1500-1900: Migrations, Settlements and Socio-political Development (Lagos: Raytel, 2003), 212.

27. Ibid., 215. 
Not only does this argument disagree with the notion of one big wave of migrations to the coastal parts, but it is able to separate the activities of the Yoruba and Benin in the process of state formation.

By the time we get to the third phase in the stories of migrations and movements, it is clear that we are encountering state formation. Thus, stories of Benin's inroads to the coastal areas to its west are also stories of Benin's empire building. Benin's expansionist policy was ambitious and its reach was extensive, stretching as far away as Porto Novo. As Benin expanded, so did Oyo, but Oyo built a much bigger empire. Thus, there are various narratives, some embedded as narratives of empire from the palaces of the conquering kings, where those living in the coastal places are presented as militarily weak or living in disorganized societies. And within the coastal areas are stories of power conflicts and power shifts, leading to more contests for power. Yoruba-Benin institutions spread remarkably well, which explains many similarities in practices.

In spite of the records of Benin's activities, allegiance of the coastal people to the Yoruba seems stronger in many areas than the loyalty to Benin, even among some communities who originally traced their origin to Benin or at a time in the past regarded themselves as Benin-dwellers. Was there a shift in self-definition at a point in history? This allegiance to the Yoruba is heavily referenced in many historical traditions that link creation and early histories to Oduduwa and Ile-Ife or to the imperial state of Oyo. And even in the case of Benin, stories of origin connect its history and dynasty to Ile-Ife. Here is how Ajetunmobi resolves the issue regarding allegiance to either the Yoruba or Benin:

the various groups exhibit impressive traits of Yoruba cultural values which they emphasize over non-Yoruba (Benin or Egun) traits. Thus, for instance, some of the kingdoms that claim origin from Benin have come to accept Awori and Ilaje Yoruba values. The claims of dynastic origin from Ife and royal links with Oduduwa have to reflect the dominant themes in ethnic consciousness and socio-political re-alignment in twentieth century Yorubaland. After all, such claims are often used to explain respectable ancestry, win elections, gain recognition as first or second-class Oba as well as acquire other privileges. ${ }^{28}$

The connection between past history and contemporary political privileges that Ajetunmobi asserts points in the direction of separating historical process from political outcomes. The process itself, of how the Benin and Yoruba penetrated the region is one thing; the outcome of reinterpreting that process in

28. Ibid., 215-16. 
line with shifting politics is another. Did oral narratives shift at various times over the years? This may very well be the case.

It is not always clear where to end the third phase in the historical evolutions of various places, if it began with the rise of Benin and Oyo after the fifteenth century. Sometimes, events of nineteenth-century Yoruba warfare are worked into stories in a very confusing manner. What I characterize as the third phase is what the co-editors of the book on the Awori call the second. Here is how they explain it: "Second, is the series of waves of migrations and settlements in Aworiland consequent upon the political crisis in the interior Yorubaland and the wake of Benin interest in the coastal corridor." 29 This was most likely a very long process, covering centuries, and could not have come soon after the founding of those communities, otherwise the stories of initial founders would have been erased. There is a need to study the phases of Benin and Oyo imperialism as distinctive but this has to be separated from the calamities of the nineteenth century.

This imperial story probably merged with a fourth and related phase triggered by the Atlantic slave trade. Too many migrations are reported during this era, from the sixteenth century onward, some internally within the region, some following trade routes. Powerful individual and state forces, far more dominant than the small communities, emerged: European traders in search of slaves and exchange markets, and the menacing empires of Dahomey, Benin, and Oyo in search of opportunities to insert themselves into and benefit from the much wider Atlantic slave trade. Around Lagos and Badagry, notice the rise of Agaja Trudo of Dahomey and his crushing inroads into the Awori region. Almost certainly, many new settlements emerged in the coastal areas claiming Aja and Benin lineages and origins. The process of how former imperial overlords became integrated into the indigenes needs be studied. Also, the multiple strands in culture, what we will see as variations of Yorubaness, need to be accounted for.

Finally, we look at the trend since the 1880s with the European conquest. Politics and economies were reordered, Lagos expanded, people moved in and out of coastal Yorubaland, and formal institutions began to replace looser ones. The coastal Yoruba became incorporated into the larger world of colonial Nigeria and modernizing Africa. In almost all of the accounts, early history is followed by the adoption of a kinglist, and the weaving of key events around those kings. There are networks of dynastic powers, in which a long list of villages is supplied, to show how a king exercised power over an area. Today, many are now called kingdoms or have "land" added to a group name to connote an expansive polity.

29. Ajayi, Ajetunmobi, and Akindele, A History of the Awori of Lagos State, 4. 
Information is supplied in the chronicles on a third set of ideas: chieftaincy and political institutions, how chiefs are installed, and institutions of governance. Here, what the writers and narrators describe regarding the political system and the judiciary tends to follow the practices of the other Yoruba towns. All attempts to codify the list of kingmakers who appointed the kings are probably to stabilize the system. Thus, Iyaomolere ranks the kingmakers for the Ilaje as comprised of the Yasere, Jadigba, Urayen, Asaron, and Asogbon. Other writers did something similar. There is a complicated network of titles linking major towns with clusters of villages, as in the case of the Amapetu of Mahin and several chiefs under him. This is a device to establish a political hegemony over an expanse of space, and to justify demands for tribute.

Various studies speak to economic issues in the coastal Yoruba regions: its economic activities revolve around the use of land, river and sea in occupations organized around fishing, hunting, salt production and manufacturing of various items. Littoral economies thrive in the abundance of life in swamps, mud, creeks, brooks, waterways, seas, and rivers. Waterlogged whenever it rains, aquatic vegetation survives, producing its own grass, and trees that can be cut and used for building purposes. A significant source of income derives from the palm-wine trees that supply oguro, and tombo used in gin distillation.

There are the aquatic-related occupations as in fishing and salt making. There are the highly specialized ways of making iyanma, obiriki, awo, and ojijon. There are weavers, farmers, and of course traders. The coastal parts have also always been suitable for carving, mat making, hunting, and lumbering. Diviners and medicine makers abound. The main features of the economy revolve around agriculture, crafts, and trade. Due to the nature of the soil, the key product that fueled the colonial economy, cocoa, does not do well here, but food crops are well established. Division of labor is gendered, as more women than men tend livestock. Palm products are important for both local consumption and export.

Trade in salt and fish is extensive. For over a hundred years, improved transportation systems, based on networks of roads and waterways, have facilitated greater exchange with the rest of the Yoruba and the West African region. One area to study is the supply chain between the coastal areas and the rest of the region to understand who dominates the middlemen's position. Did more traders go to the coastal parts to buy salt and fish or did the coastal traders themselves carry these products to land-based markets?

The mobility of the fishing industry is usually underplayed, as it is treated as excessively local. Not so; the industry is complex. Fishermen and women travel widely, as in the case of the Mahin who can be found in many states today (Lagos, Ogun, Osun, Oyo, Ekiti, Edo, Delta, Akwa Ibom, Cross Rivers, Bayelsa, Rivers), and the Ikale and Ilaje in those areas as well and along the West African coast. 
All the authors touch upon social and religious matters such as marriage, death and burials, and the changes they have noted in time in their own era. There are sporadic variations in the records consulted by scholars, but academic presentations on marriage, birth, death, and celebration tend to fall into what we characterize as Yoruba. Festivals show some peculiarities, as in the Erejeriko and Ere among the Mahin. Deities include some major ones, such as Ogun (the god of iron), but many minor deities, as in the case of the Mahin (Orunmita, Maloku, Oghoye, Ohajofi, Paramo, Opan, Eghare-Igoro, and Ogun Alagwe) may not be as well known. Christianity penetrated all the areas from the nineteenth century, and there is also the spread of Islam.

The authors narrate history, skipping parts where oral accounts are weak or non-existent, or where progress cannot be reported. They close with the contemporary activities of politics and civic duties. The aspects of contemporary history revolve around development-how communities, villages, and towns are to be physically enriched; and how their children will receive good education and live a better life. In the literature, specific issues are provided on modernization, the role of politics and political leaders, and highlights on successful sons and daughters.

No doubt, given the abundant resources of the region, which include bitumen and oil, the residents are not just seeking changes, but are part of the overall development engine of Nigeria and the larger West African region. The current struggles for development are the critical issues that will continue to instigate interest in the past, and the mobilization of coastal Yoruba for political relevance.

\section{Development, Intersectionalities, and Hybridities}

Today, nothing is more important to the coastal Yoruba people than the development agendas and concerns that drive their interests. While we present Lagos and Badagry as cosmopolitan, and celebrate their long history of modernity, we must also see how, in many parts of coastal Yorubaland, the ruins of modernity are everywhere to see. As the state appropriates land, it pushes people into swamps and poverty; as habitats are destroyed and polluted, lives are damaged, economies ruined, and the eco-system destroyed. In some places, the faces of the contemporary times are the faces of squalor and ugliness. Thousands of people inhabit ruined spaces, living as squatters in their own land.

There are a number of concerns and growing tensions at present. Of the myriad, four stand out:

- Land dispossession in lucrative areas as among the Awori where reclamation projects push out indigenous landowners to fend for themselves. 
- Economic marginalization and underdevelopment where access to fishing and farming is reduced.

- Migrations and encroachments: Those who regard themselves as the indigenes of Lagos are disturbed that immigrants from other parts of the country lay claim to their land, dominate the economy, and now want to control power. Notice here the following complaint: "the Aworis more than any other sub-group of the Yorubas have witnessed constant bombardment by non-Aworis and non-Yoruba groups. The effect is a cultural pollution, linguistic adaptation and social transformation." ${ }^{30}$

- The presence of bitumen, oil and gas. How will these be used? While natural resources are a source of strength, they also pose a severe threat to the survival of coastal cities. They are victims of stronger neighbors and generally of predators seeking to harness those resources. Whether in the past or present, coastal cities are poached upon.

Contemporary political issues have arisen, making it important to study all the coastal communities. One pressing concern is indigeneity, the question of who owns a place and since when. This issue is more divisive in Lagos where the Awori see themselves as indigenous and some other groups contest the claim. Benin's approach to history claims for itself some kind of primacy, while some fringe accounts even trace connections to the Igbo. Due to the intensity of migration to Lagos, and the large-scale presence there of other groups from Nigeria, attempts at obtaining power and resources are often located in revising history.

Where there are resources of crude oil and bitumen, the people have also become politically active and restless, demanding that their areas should see development. Gbade Ikuejube, writing for the Ilaje of the Niger Delta, in a passionate manner, reveals the overall state of anger and disappointment that the people go through. Ignoring his various typographical and language errors, part of his key concerns are reproduced below:

The high expectation of Ilaje people for improved living condition since the commencement of oil exploratory activities had been dashed. In a bid to address this predicament the Ilaje people have been expressing their grievances in diverse ways.

The state of abandonment of communities in Ilajeland could be seen in the areas of lack of basic socio-economic infrastructures that could engender social and economic growth. Motorable road [sic] electricity and health facilities are rare commodity to the Ilaje people. Water which should have being [sic] a compensatory commodity in Ilaje region has been polluted by the activities of the oil companies. Surface water and

30. Ibid., 4 . 
rivers are undrinkable. This situation therefore rendered unsafe for human consumption the natural water in Ilaje area of the Niger Delta. It was this development that pitched the Ilaje people against government on one hand and the oil companies on the other hand. The Ilaje people of the Niger Delta region believe that oil companies and the Federal Government are collaborators in this matter. This predicament led to the formation of pressure groups ethnic militia and other militant group [sic] in Ilaje area of the Niger Delta. Some of the groups include:

- The Gwama Boys

- The Ilaje Patriotic Front

- The Ilaje-Ugbo Youth Forum

- The Ilaje Niger Delta Youth

- The Ilaje Niger Delta Congress of Nigeria

- The Council of Niger Delta Women of Ondo State

- The Ilaje Environmental Right Association

- Ugbo Central Council

- The Traditional Rulers Forum

- The Ilaje Christian Soldiers

- The Ilaje Volunter (sic) Services

- The Voice of the Niger Delta Women of Ondo State

The main aim of this group is to protect the interest of the Ilaje people in the Niger Delta. As a result of their activities there have been clashes with the Federal Government on the one hand and the oil companies on the other hand. ${ }^{31}$

The advantages of this region remain, and how they will benefit the people is a question for the development agenda. Coastal settlements have a tremendous advantage of location. They combine the diverse riches of the sea, and of the rivers that flow into them, in many ways: fish, crabs, alligators, and hundreds of other aquatic animals, full of protein. Salt, where this can be processed, can also be added to this list, along with various plants of medicinal value. Coastal areas supply those needs that are basically essential to human survival, as in the case of salt, and to human health, as in the case of fish.

\section{Conclusion}

Let me make a number of suggestions to move forward both the practical development and academic research agendas. The first is on what the people

31. 'Gbade Ikuejube, Ilaje: The Yoruba Fishing People of the Niger Delta (Oka-Ondo, Ondo State: Self-Published by Novec'kol Printer, 2005), 54-55. 
want: development. The government at all tiers must use the money made from the areas to develop the people of those areas. And additional sources have to be tapped. Coastal parts are linked to tourism as in the development of beaches. There are small islands that can add intrigue and pleasure to a visitor's experience. With many areas still undamaged, attempts should be made at preservation, and even transformation into exclusive places. Hidden mysteries and sites have to be revealed and converted into useful and profitable centers.

To turn to the agenda on the future of scholarship, at a collective level, attention must be paid to the following.

\section{Methodology}

How do we make future studies more systematic so that, at the very minimum, there is consensus on the validity of historical data generated from fieldwork? Coastal Yorubaland is not unique as regards the limitations in the depth of history, as in limited knowledge for centuries preceding the nineteenth century. How do we avoid generalizations so that, at least, we understand the peculiarities of coastal Yorubaland? Extensive data have to be collected, since written documentation is rather scanty. Lagos and Badagry are privileged with a better database but not the rest of the coastal region. All the available written sources dating to the early encounters with the missionaries have to be collected and digitized. For the long period before the nineteenth century, there is not much in the way of written sources to talk about. Written sources are virtually nonexistent for the majority of the coastal towns and villages, and where any exist, as in the case of the meagre ones obtained by Europeans in Benin and Whydah, they tend to be based on hearsay and somewhat unreliable. Thus, there is no alternative to turning to traditional accounts in the various forms that have been handed down from one generation to another.

Corruption has increased in scale and scope to damage many elements of traditional accounts as narrators are guided by all sorts of patriotic motives and even by selfish considerations of money and politics. Oral data have their limitations, most especially when the motive of the collector and chronicler shapes what is collected, and how the stories and interviews are presented. But they cannot be dismissed on the ground of their limitations. Scholars just have to be more careful as to how they will use the accounts and evaluate them. We have to be alert to understanding the motives behind the stories, the propaganda elements in the narratives, and the corrupting influences of money. The real danger is when there are scholars with similar mindsets as the local chroniclers.

The political ideologies and propaganda behind the revision of older mythologies must be borne in mind. In an act of reversal, the last Oba of Benin revised the established stories of Ife's impact on Benin to argue that it was Benin who sent Oduduwa to Ile-Ife. In recent years, and in many places, the 
stories have been driven by the need to know the past (a noble motivation) but also with a practical purpose. This is usually for a community to define its land and territories in ways favorable to it and to make a claim to Obaship, essentially the right to wear crowns. Distortions have become widespread, complicating historical work. In other words, there is a politics of history. Revisionist history borne out of the need to be different, independent, and recognized could easily tarnish the authenticity of records. Yet, we must continue to collect and preserve the traditions. Students of history (scholars) must embrace objectivity in their careful documentation of historical records.

Data have to be collected on each town and village, to gather their intellectual resources. The old-fashioned way of getting committed and sincere undergraduates to undertake Honors projects is one approach. The other is collaborative work that may involve research teams, as was attempted in the 1950s at the University of Ibadan and in the 1980s at the University of Ife.

There are actually a number of data sources that are less problematic, such as songs, proverbs, performances, and ceremonies. The idea is to treat them not just as sources of history, but also as ontologies and as epistemologies. For too long, we have been seeking nuggets of historical data from these other sources and approaches at looking at society, but without also seeing them as other forms of knowing. Society can be interpreted through objects, arts, archaeology, and a lot more, and these forms of knowing have their own integrity. It is when we want to force forms of knowing into Western historical paradigms that we run into intellectual predicaments.

\section{Conceptualizations}

All the concepts we use must always be clarified. One key element of clarification is to work out a timeline of events and significant phases from the very early period. A starting point is the compilation of lists of rulers, and to begin a process of matching the lists in one area to another and establishing a time frame. This will be useful in clarifying origins and spread of ideas. Issues around the meanings of words and ideas indigenous to different areas must be spelled out, if only not to engage in generalizations within a pan-Yoruba framework. Future studies must move away from the definitional pessimism that cuts off the history and society of the coastal areas, to a definitional optimism that includes them within the larger Yoruba and Nigerian historiography.

How did decentralized communities become centralized and governed by kings? On the one hand are stories and accounts that speak to the emergence of small communities operating more as chiefdoms, but on the other is the evolution of kingship. Today among the Awori are such kings as the Onijanikin of Ijanikin, the Olofin Adimula of Iseri, and the Oloto of Oto-Awori. Not only 
do we have to clarify the labels and titles we use, we must also locate them in specific historical moments.

\section{Metaphysical and Ontological Considerations}

Among the data to seek and interpret are those on metaphysical thinking, oriki, riddles, divination, magic, charms, witchcraft, the connections between spiritual and religious and economic behaviors and practices. In addition, knowledge needs to expand on architecture, several aspects of culture as musicology, arts, costumes, ewo (taboos), drama, and beyond. Questions must be raised. For example, what is under the sea? Tales of water gods and goddesses are essential components of our narrative continuum. Aiyelala is a prominent religious phenomenon, one of the most established beliefs with widespread discussion. ${ }^{32}$ Another question to be asked is how do ideas around the unknown affect quotidian practices?

\section{Epistemological Considerations}

New integrative fields and approaches must emerge. It is important to link the environment and biology of the coastal areas to their cosmologies. Indeed, I want to propose the creation of a field to be called Cosmic-Ecology. The proposed field will fuse data from biology and physics to that of spirituality. Water deities, space spirits, and water and land will become conjoined. The field of ethnobiology will also need to be developed, to focus on this region. This will merge the celestial, the terrestrial and the aquatic in a single epistemological thread.

\section{Social Impact}

How the people's lives are linked to necessity and chance should be studied in its multi-faceted reality. As I pointed out above under "Significance," the coastal parts must be linked to how we study and present tourism. A large expanse of area has actually been under-explored.

\section{Themes}

There are many themes and topics that have to be pursued and developed, and many can start as $\mathrm{PhD}$ dissertations to be later developed into major essays and books. A few topics and themes include the following:

i. Religion and Spirituality: This is a necessary fusion of knowledge that needs be studied. There are stories, mythologies and practices peculiar to

32. See Joseph Omolade Awolalu, "Aiyelala: A Guardian of Social Morality," Orita 2:12 (1968): 79-89. 
coastal cities, and these must be connected to the meanings and institutions of politics and how society functions in general. For instance, the Zangbeto, wearing their raffia symbol, became the security guards among the Egun, serving as the vigilante groups to protect towns and villages. There are borrowings among different religions-what some label as syncretism - and we need to know what Islam and Christianity owe to local religions and vice versa. So also are the connections between religious practices and economic activities over time. In what ways do religion and politics interface with and impact one another? How is religion related to competition for power, and to legitimate and illegitimate means of acquiring and using influence? Is "magic" connected with crime-economies as in the examples of money-making rituals, and modern-day kidnapping, oil bunkering (stealing refined oil) and robbery?

ii. Changing Landscapes: This is a theme that must be pursued by a team of physical and social scientists, in partnership with historians. Landscapes are not always fixed in time, and certain aspects of them do change over time. Encounters and relationships between humans and the landscape also change. The coastal Yoruba would have changed the landscape over time. In the process, the culture changes and adapts, while vision also becomes elastic.

iii. Migrations, War and Peace: Historical consciousness must continue to develop, and this may be fueled by more interest in early history, mythologies, origins, and inter-group relations.

iv. Coastal Nature and Nurture: These will be full-blown studies of environmental history. Marine life has to be part of biology and microbiology classes. The changing role of the seaports and ways to design and build new ones can be part of development thinking.

v. Comparisons: Studies have to look at various ways of doing things as in the case of the same identity group that is both land-based and sea-based, as in the example of the Awori, some of whom live in the coastal areas and some in Lagos and Ogun State. Studies can also look at different practices along boundaries, such as along the international one between Nigeria and the Republic of Benin, and local ones such as define the cultural frontiers of the Yoruba and Niger Delta. "Border townships" can generate their own set of studies, as in the analysis of bilingualism. Where immigrants among the coastal Yoruba have the status of "strangers" or "settlers," their activities can be compared to the indigenes' in various aspects: religious and economic practices, different fortunes and opportunities.

vi. Historical changes in all aspects of society, as in the spread of Islam and Christianity, Western education, changing economies in the context of formal and non-formal sectors. 
vii. Philosophy of Life: there should be a series of studies on the impact of the sea and water on religious life.

viii. Popular Culture: We have to fuse modern popular culture with modern popular politics. New forms of religious practices and protestations feed emergent popular politics. Ruins and God are connected in images, preachers in their sermons, etc., to speak to the sins of leaders and inadequacies of governance institutions. Sermons are many about salvation and worldly survival and they do intersect with politics.

ix. Changing Economies: There is the pressing need to look into the changing economies, from the precolonial to the present, with attention to the emergence of new forms of economies as in smuggling, bunkering, kidnapping, etc.

x. Biographies: In local history books, there are references to many prominent figures, political leaders, missionaries and others (e.g., Ola Avoseh, Hundeyin, Oba C. D. Okran of Badagry). There is a need to compile more names and do research on many of these people.

xi. Tourism: Scholars must trigger and become involved with the compilation of all the important resources, and study how to make them visible and connect them to economic activities.

\section{Units of Study and Analyses}

As we organize the data and clusters, attention must turn to several levels of integration of coastal Yorubaland with various bodies of knowledge and historiography. I propose four major units.

The first concerns integration with the larger Yoruba-Benin region (as macro history). The communities have to be studied in larger regional networks of Yoruba, Edo and Niger Delta spaces. Take the Mahin people, for instance: they have the Ikale to the north, the Edo in the north east, the Ijebu to the west, the Ugbo and Itsekiri to the east. The relationship between the Yoruba close to Warri, with the Itsekiri as neighbors, reveals how cultures and people mingle, as the Itsekiri speak, to quote Daryll Forde who wrote as far back as 1951, "a divergent Yoruba dialect," although "their social organization like their speech has been modified by Edo (Bini) connections, their ruling lineages being held to be descended from an early Benin Oba, while their economy is similar to that of the Sobo (Urhobo) and Ijaw." ${ }^{33}$ In this regional unit of analysis, the littoral and the hinterland are linked. In this regard, I suggest that we do not look at the coastal parts as ordinary peripheries but as dynamic agents of history in a larger regional framework. As dynamic agents, there is traffic of people and

33. Forde, The Yoruba-Speaking Peoples of South-Western Nigeria. 
ideas between places, as in the activities of traders, religious missionaries, itinerant preachers, and fishermen.

The second is the unit on the coastal communities (micro history). The need for each community, cluster of communities, and subgroups to know their history is great. Here is a justification provided by the co-editors of the book on the Awori:

Aworiland as a melting pot of cultures and people is indisputable, but the region and people are fast losing their identities because of cultural infiltration and heterogeneity of its inhabitants. Things that are of Awori origin are fast fading away. The peculiar twentieth century Nigerian problems are making the matter worse. The indigenous people who used to be the custodians of their community histories are aged and diminishing in number, the younger generation are not well-grounded in the history and traditions of the land having been sent to western schools where these things are not taught; given the widespread apathy for history, they do not stand a chance of knowing the history of their motherland but for the type of rescue operation carried out in this exercise. ${ }^{34}$

The coastal areas have to be studied as a unit of analysis, to create their own specific ontologies and epistemologies. Small communities were scattered over the entire coastal region, and their activities need to be understood at several levels: their mobility and mode of production to make a living for themselves, construct survival mechanisms, and relate to one another. They also had to develop inter-group relations while negotiating with such power centers as Oyo and Benin. These places have to be studied as interacting across both land and water. Take, for instance, the Mahin: they have communities on land (Oke-Etugbo, Okonla, Ebute-Ipare, Ayetitun, Oke-Ereke, Olokuta, Igbolomi, Igbobi, Itebu-Kunmi, Itebu-Manuwa, Ago Fayemi, Mahintedo, Igboegunrin, Eyinoha, Kurugbene, Kema, and Olomidudu, to list some examples). And there is a long list of over fifty littoral communities (for example, Iloro, Igbokuta, Oropo, Oke Edeba, and Etugbo). The study of coastal Yorubaland should be elevated to a subfield of its own, as a unit of analysis represented in the academy, the constitution of knowledge and teaching. As a cultural and geographic unit, the people who inhabit the long stretch between the Ewe along the coast of Ghana and the Ijo in the Niger Delta may be framed differently from the way they have been partitioned by the Europeans into different countries and converted into minorities in all of them.

34. Ajayi, Ajetunmobi, and Akindele, A History of the Awori of Lagos State, 3. 
The third unit concerns the whole of Nigeria (national history), and how to integrate the coastal Yoruba people into the mainstream of Nigerian history. Lagos and Badagry are already integrated, but not the rest.

The fourth situates coastal Yorubaland within Atlantic history (global history). Coastal Yoruba people cannot be cast in the mold of the "local" as in the terminology of local histories, because while they represent communities in specific geographic spaces, they have all been connected with larger regional politics and international trade. ${ }^{35}$

With my suggestions and those of others, this conference may very well mark the beginning of a new era in Yoruba scholarship that will be complementary, supplementary, and definitive with attention to coastal Yorubaland and the interrelatedness of religion, trade, and politics.

35. See, for instance, Kristin Mann, Slavery and the Birth of an African City (Bloomington: Indiana University Press, 2007). 
